\title{
Research on the Influence of Migrant Workers on Rural Construction and Economic Development
}

\author{
Wang Yuping \\ College of Environment and Resources, Wenshan University, Wenshan, Yunnan, 663099
}

Keywords: Migrant workers; rural construction; economic development

\begin{abstract}
A large number of rural labor forces have a negative impact on the local economy and society. Rural labor force plays an important role in relieving the poverty and increasing the income of rural residents to improve the welfare of the family; Labor mobility also promoted the flow and reorganization of capital, land and labor resources in a certain extent, it promoted the deepening of specialization and division of labor and rural market of rural production in some degree. Due to the fact that a large number of young men in high education work out of labor, it not only increases the labor intensity of rural areas, but also brings some negative effects on the popularization and application of advanced agricultural technology and the development of modern agriculture. Therefore, the local government should integrate the advantages and disadvantages of migrant workers to work, and formulate appropriate local policies to promote the construction and development of the rural areas to the greatest extent.
\end{abstract}

\section{Introduction}

With the rapid development of productivity and economy in China, there are more and more rural surplus labor force, and the gap between urban labor force and rural labor force is increasing. The flow of rural labor in China began in the early 20th century, and experienced a phased change in scale. With the acceleration of rural economic development, urban reform and the process of opening to the outside world, it reached a climax [1-2]. In the early 20th century, migrant workers were less than ten thousand people, more than ten thousand people in recent years, and then increased to 10000 after the year. According to the National Statistical Bureau's national economic and social development statistics bulletin, the total number of migrant workers in the whole country is ten thousand, increasing over the previous year [3]. Among them, tens of thousands of migrant workers will increase the growth of the local migrant workers. At the same time, there are also changes in the migrant workers. The new generation of migrant workers born after that year has gradually become the main body of migrant workers and is playing a more and more important role in the whole economic society.

\section{The positive influence of peasant migrant workers on rural construction and economic development}

The rural migrant labor force, the rational allocation of labor resources, to promote the agricultural labor force to achieve effective migrant workers in the two or three industry; gradually reduce the excessive pressure caused by the agricultural labor force to society; promote the development of rural economy, promote urban and rural economic and social development complementary; increasing peasants' income people's lives has played a very positive effect.

\subsection{Promoting the transfer of agricultural labor to non-agricultural industry}

In twenty-first Century, along with the development of non-agricultural economy change rapidly, especially in the eastern coastal developed regions of non-agricultural economic leap, rural labor force no longer meet in a very limited liability field "sunrise evening", a large part of the original engaged in agricultural labor from the land of migrant workers migrant workers. From the employment point of the industry, the rural labor force of migrant workers are mostly distributed in 
the industry, construction industry, service industry, wholesale and retail trade, catering industry and transportation industry [4]. In the three industrial structures, the foreign workers and peasant workers engaged in the second industry accounted for the third industry, and the first industry (Agriculture) accounted for only. The effective migrant workers from agricultural labor to non-agriculture have improved the non-agricultural rate of rural labor.

\subsection{Broadening the farmers' economic income channels and promoting the growth of farmers' family income}

The migrant workers in rural areas have accelerated the migrant workers' migrant workers, which directly increases farmers' non-agricultural income, and thus promotes the growth of farmers' income. From 2012 to 2016, the per capita net income of farmers increased from 3277.36 yuan to 6438.07 yuan, and the annual increase was shown in Table 1 and Figure 1. The income of rural labor force has kept rising, which has supported the growth of farmers' income.

Table 1. Annual change form for farmers' income

\begin{tabular}{|c|c|c|c|c|c|}
\hline Project & 2012 & 2013 & 2014 & 2015 & 2016 \\
\hline Total income & 3277.36 & 3431.47 & 4402.6 & 5508.56 & 6438.07 \\
\hline Wage income & 612.78 & 483.68 & 955.46 & 1189.73 & 1282.08 \\
\hline Household income & 2560.58 & 2905.44 & 3398.82 & 3918.08 & 4816.54 \\
\hline Property income & 55.36 & 16.18 & 23.34 & 236.65 & 22.08 \\
\hline Transferable income & 48.64 & 26.17 & 24.98 & 164.1 & 317.37 \\
\hline
\end{tabular}

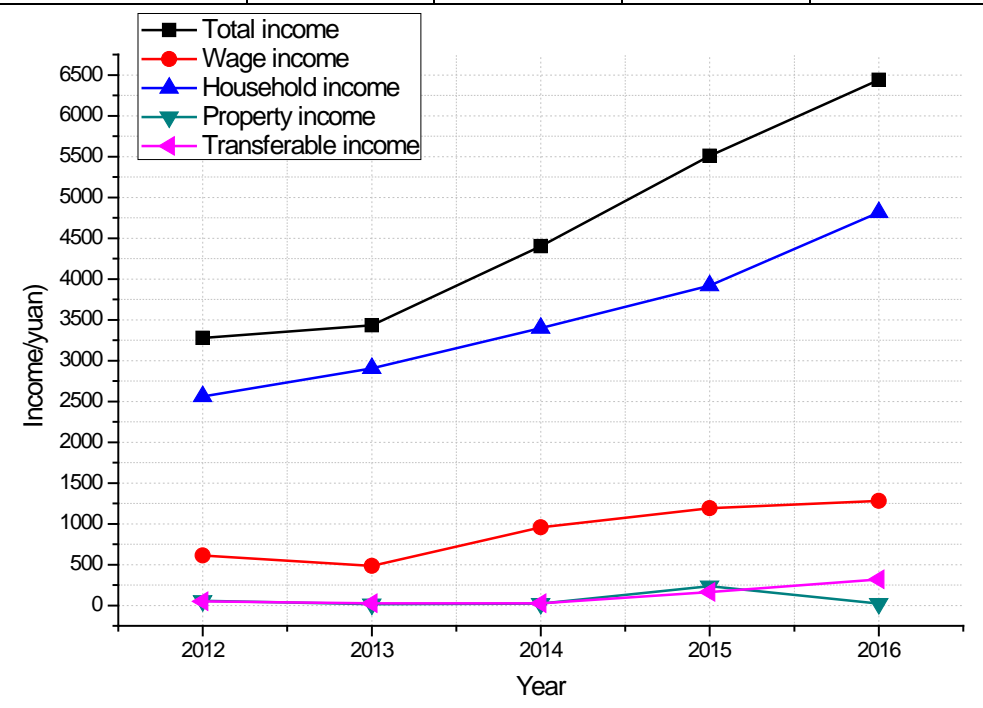

Figure 1. Annual change chart of farmers' income

\subsection{A bridge between rural and urban economic development complementation}

From the situation of employment, migrant workers enter the city, which can solve many inconveniences in the life of urban people. Most of the migrant workers are engaged in dirty, tired, bitter and urban people's not willing to do the work. They provide homemaking, medical care, sanitation, building and service industries, which are badly needed in urban life. Because of their low wage demand and low expectation of employment, migrant workers have enhanced the competitiveness of urban employment, to a certain extent, changed the concept of job hunting for urban labourers, promoting the market-oriented reform of labor employment system and the 
cultivation and development of labor market [4]. Migrant workers enter the city, accelerating the modernization of the city. Since the reform and opening up, the economy has been invigorated, the original urban construction team cannot meet the needs of the development of the city. The organized peasant construction team takes the burden bravely. They are fearless and hardworking, living in low standard and strict in work. To a large extent, they have made up for the shortage of urban construction and installation team and speeded up the pace of urban modernization. In addition, migrant workers in production activities and life consumption, which led to the development of the city wholesale and retail trade, catering, transportation, resident services and other related industries. At the same time, farmers went out to work, widened their horizons, increased their knowledge, learned technology, accumulated funds, became familiar with the market, and changed the way of thinking and lifestyle of farmers.

\subsection{Rural migrant workers play an important role in the development of regional economy}

In recent years, the increasing number of migrant rural labor, forming a powerful "wage tide". Rural labor force to work out to promote the development of regional economic development is related industries with migrant workers have been developed. With the growing ranks of migrant rural labor, and some of the migrant workers and intermediary service industry has emerged, transportation, real estate, commercial catering industry and other related industries has also been considerable development; two is rural migrant labor income huge amount, capital accumulation effect [5].

\section{The negative effects of migrant workers on rural construction and economic development}

Migrant workers from rural labor to some extent have promoted the rapid development of regional economy, but there are also some problems to be paid attention to.

\subsection{The work of migrant workers in rural areas has caused the waste of land resources and the difficulty of land circulation}

With the promotion of agricultural modernization, the contradiction between the requirement of modern agriculture on scale economy and the current decentralized contracting land system land increasingly prominent, the household contract responsibility system has not adapted to the current modern agriculture to highly concentrated land and contiguous planning, mechanization of farming needs. On the other hand, land contract and the lack of flexibility, inconvenience of land gift circulation, leading to rural land disputes, some rural labor although years of overseas workers, even some families go out, don't give up on the contracted land endowment, to the rural land circulation has brought many difficulties [6]. The low agricultural efficiency, rural migrant workers have, to a certain extent lead to the rural land cultivated unabated, the harsh reality was a wake-up call to the world.

\subsection{The work of migrant workers in the rural young and young years leads to the poor adjustment of the agricultural industrial structure}

Because most of the young farmers who have much higher education have gone out to work or do business, most of the left behind farmers in the countryside are middle-aged or old labor force older than the age. Their cultural quality is not high; the market consciousness is weak; the farmers' market information is blocked; the planting structure is adjusted to the large stream. From a nationwide perspective, the characteristics of agricultural areas are not obvious, and the dominant industries such as aquatic products, livestock, fruits and vegetables are not large enough to make full use of comparative advantages, and farmers' income is not stable and unstable [7].

\subsection{Migrant workers have hindered the development of agricultural industrialization}

The pulling effect of agricultural organization role and leading enterprises is not enough, within the city to participate in rural cooperative economic organizations of farmers is less than $9 \%$, there is in direct contact with the leading enterprises of the farmers is less than $40 \%$. The real order 
agriculture is not yet available, and a large number of farmers are still hovering outside the "industrialization" door. In addition, the development of farmers' professional cooperatives is lagging behind, and some local and part industries have not established professional organizations in rural areas.

\section{Countermeasures and suggestions on migrant workers}

\subsection{Vigorously develop township enterprises, farmers and encouraged farmers to leave their homes}

"Township enterprises" mainly refers to the enterprises that are directly related to the interests of farmers in rural areas, using rural resources and rural labor as the main human resources. As an important way to solve the problem of increasing income and absorbing surplus labor force of rural migrant workers, township enterprises are also effective measures for rural farmers to live away from the land without leaving the home and away from home. Township enterprises are facing financing difficulties, the problem of shortage of funds and other external development of the main body of market competition, it also has the low level of industrial structure, the enterprise operator quality is not high, short survival time, science and technology strength is weak, the plight of poor material and technical equipment [8-9]. Overall, the rural agricultural industrial structure is not excellent, it is necessary to change the mode of agricultural development and focus on the development of the characteristic rural agriculture.

\subsection{Strengthening the management of the rural society and solving the problems and difficulties of the disadvantaged groups}

Rural government departments should organize their strength, make plans and go deep into families, so as to solve the practical difficulties of rural left behind personnel, so that the left behind elderly children can be relieved when they are in difficulties. For children, school teachers are required to implement "one to one, one to one" approach to child care, to care for and help children grow; for the elderly, the elderly can arrange regular visits to families, regularly arrange doctors' physical examination [10]. Especially in the rural township government should increase investment in rural public health, accelerate the construction and transformation of township hospitals and village clinics; the construction of urban and rural social security system, improve the medical security level of farmer participation, to further promote the new rural endowment insurance policy; improve the rural elderly, left behind children, elderly people living alone and other special survival in the crowd, to create a good social atmosphere for the whole society to care for the people left behind.

\subsection{Introducing the policy of benefiting farmers and strengthening agriculture and absorbing the outgoing people to return to their hometown}

From the part of the rural elite home business, on the one hand, the majority of migrant workers is founded by township enterprises and business, to absorb the surplus rural labor amount; on the other hand, there is a big gap between the operating characteristics of agricultural enterprises wages and city wages, although unable to retain qualified labor force, but always keep a group. In view of these conditions, we put forward some financial support for the enterprises of migrant workers returning home to operate the characteristic agriculture. With the government's financial support, more migrant workers can go back to their hometown to start running characteristic agriculture, and at the same time, they can increase wages for inaugural farmers. Therefore, the introduction of the policy of benefiting farmers will help the rural elite return to their hometown.

\section{Conclusions}

Migrant workers in rural areas are an irreversible phenomenon in the process of modernization. We need to recognize and address of migrant rural labor of the positive and negative effects through the development of township enterprises, farmers and encouraged farmers to leave their homes; 
strengthen the management of rural society, solve the difficult and vulnerable groups worry; strengthen personnel training, to promote the level of migrant workers; the introduction of strong agricultural policy, the absorption of migrant workers back home; rich farmers the cultural life, promote civilized new rural areas is a series of measures and reform, population mobility and the development of agricultural scale management combine to attract young people engaged in agriculture; adopt preferential policies, to improve the quality of agricultural labor force, strengthening the construction of rural grassroots cadres, vigorously promote the construction of rural social undertakings, improve rural people's livelihood.

\section{References}

[1] Lu J K, Yin X J, Watanabe T, et al. Physiques in Migrant Peasant Worker's Children by Comparison with Rural and Urban Children in Shanghai, China[J]. Advances in Physical Education, 2014, 04(1):10-24.

[2] Xi M, Zhu J, Economics S O, et al. Land, Housing and Citizenization of Rural Migrant Workers: Based on Dynamic Monitoring Data of Floating Population [J]. Future \& Development, 2017.

[3] He L. OA2 Chinese migrant peasant workers and the contradictory demands of filial piety in neo-liberal chinese society: a case study of filial end-of-life care in langzhong city [J]. Bmj Supportive \& Palliative Care, 2015, 5 Suppl 1(Suppl 1):A1.

[4] Cheng Z. The New Generation of Migrant Workers in Urban China [M]// Urban China in the New Era. Springer Berlin Heidelberg, 2014:125-153.

[5] Yang H, Gao J, Wang T, et al. Association between adverse mental health and an unhealthy lifestyle in rural-to-urban migrant workers in Shanghai[J]. Journal of the Formosan Medical Association = Taiwan yi zhi, 2016, 116(2):90-98.

[6] Qiao J L, Zhang X T, Cheng Q Q. Based on the Competency Theory of the New Generation of Migrant Workers Professional Ability Study[M]// Proceedings of the 6th International Asia Conference on Industrial Engineering and Management Innovation. Atlantis Press, 2016:23542362.

[7] Yun L, Yunhui L. New Identity, New Mission: A Survey on Contemporary Migrant Workers in Beijing [J]. Canadian Social Science, 2014, 10(6).

[8] Dengguo, ZHANG. Analysis of Peasant Workers' Citizenization and Social Integration in the Perspective of Social Concern [J]. 2017(6):63-65.

[9] Ye P, Wu X, Keita H, et al. Knowledge, attitudes and behaviours related to HIV/AIDS among female migrant workers in the restaurant industry in Guangzhou, China. [J]. West Indian Medical Journal, 2013, 62(4):329-36.

[10] Betancourt T S, Shaahinfar A, Kellner S E, et al. A qualitative case study of child protection issues in the Indian construction industry: investigating the security, health, and interrelated rights of migrant families [J]. Bmc Public Health, 2013, 13(1):858. 